\title{
DETERMINANTY ORAZ SPOSOBY OGRANICZANIA WYKLUCZENIA FINANSOWEGO OSÓB BEZROBOTNYCH
}

\begin{abstract}
Streszczenie
Osoby wykluczone finansowo, czyli takie, które doświadczają problemów w dostępie do produktów i usług finansowych w odpowiedniej dla nich formie, nie mogą aktywnie uczestniczyć w życiu ekonomicznym i społecznym. Wśród podmiotów wrażliwych na wykluczenie finansowe znajdują się osoby o niskich dochodach oraz bezrobotni. Wobec tego między innymi im jest dedykowana unijna strategia na rzecz inteligentnego i zrównoważonego rozwoju, sprzyjającego włączeniu społecznemu - „Europa 2020”. Celem niniejszego opracowania stało się zidentyfikowanie czynników determinujących wykluczenie finansowe osób bezrobotnych oraz wskazanie kierunków działań inkluzyjnych, zmierzajacych do ograniczenia tego ważnego problemu społeczno-ekonomicznego. Wykorzystane metody badawcze - model regresji logistycznej i metody opisowe pozwoliły wyciagnąc następujące wnioski. Po pierwsze, do głównych determinant wykluczenia finansowego bezrobotnych, oprócz niskich/braku dochodów, należy zaliczyć: brak awersji do zadłużania się, częste problemy z zarządzaniem płynnością budżetu gospodarstwa domowego, niski poziom świadomości finansowej oraz słabe wykształcenie. Po drugie, wśród podstawowych obszarów, w jakich powinny być prowadzone działania inkluzyjne skierowane do tej grupy społecznej, znajdują się m.in.: kształtowanie umiejętności finansowych, ochrona konsumenta, oferowanie produktów „,szytych na miarę” potrzeb.
\end{abstract}

Słowa kluczowe: wykluczenie finansowe, inkluzja finansowa, bezrobotny, model regresji logistycznej

\section{FINANCIAL EXCLUSION OF UNEMPLOYED: DETERMINANTS AND REDUCTION STRATEGIES}

\section{Summary}

Financially excluded individuals, i.e. those who experience difficulty in accessing financial products and services in the form adequate for their needs, are not capable of actively participating in economic or social life. Among people vulnerable to financial exclusion are mainly persons on low income and the unemployed. Therefore, the EU strategy for smart, sustainable and inclusive growth - "Europe 2020" is, among other things, dedicated to them. The objective of the present study is to identify factors which determine the financial exclusion of the unemployed and to indicate the directions of inclusive activities aimed at the reduction of this important socio-economic problem. The applied research methods - the logistic regression model and the descriptive method, allow for the following conclusions to be drawn. Firstly, the major determinants of financial exclusion suffered by the unemployed (apart from low/no income) include: lack of debt aversion, frequent problems with managing household budget liquidity, low level of financial awareness, and poor edu-

${ }^{1}$ Dr Małgorzata Solarz - Katedra Finansów i Rachunkowości, Wydział Ekonomii, Zarządzania i Turystyki, Uniwersytet Ekonomiczny we Wrocławiu; e-mail: m_solarz@op.pl. 
cation. Secondly, the basic areas in which inclusion activities aimed at this social group should be conducted are, e.g., consumer protection, offering "tailor-made" products, or development of financial skills.

Key words: financial exclusion, financial inclusion, unemployed, logistic regression model

\section{Wstęp}

„Europa 2020 - Strategia na rzecz inteligentnego i zrównoważonego rozwoju sprzyjającego włączeniu społecznemu” jest współcześnie realizowaną, długookresową strategią rozwoju Unii Europejskiej na lata 2010-2020 [Europe 2020..., 2010]. W dokumencie tym została podkreślona potrzeba wspólnego działania państw członkowskich na rzecz wychodzenia z kryzysu oraz wdrażania reform umożliwiających stawienie czoła wyzwaniom związanym z: globalizacją, starzeniem się społeczeństw czy rosnącą potrzebą racjonalnego wykorzystywania zasobów. W celu osiagnięcia, założeń zaproponowano trzy wzajemnie wzmacniające się priorytety:

- $\quad$ wzrost inteligentny (smart growth), czyli rozwój oparty na wiedzy i innowacjach;

- wzrost zrównoważony (sustainable growth), czyli transformacja w kierunku gospodarki niskoemisyjnej, efektywnie korzystającej z zasobów i konkurencyjnej;

- $\quad$ wzrost sprzyjający włączeniu społecznemu (inclusive growth), czyli wspieranie gospodarki charakteryzującej się wysokim poziomem zatrudnienia i zapewniającej spójność: gospodarczą, społeczną i terytorialna.

Zadaniem zawartych w tym dokumencie instrumentów realizacyjnych w postaci projektów przewodnich, zwanych inicjatywami flagowymi (flagship initiatives), jest przyspieszenie i ukierunkowanie sposobów realizacji założonych celów rozwojowych. Wśród wspomnianych inicjatyw znajduje się „Europejski program walki z ubóstwem”, który sprowadza się do zapewnienia spójności: gospodarczej, społecznej i terytorialnej dzięki pomocy osobom biednym i wykluczonym społecznie oraz umożliwieniu im aktywnego uczestniczenia w życiu społecznym. Niestety, o tym ostatnim nie można mówić, jeśli poszczególne osoby lub całe gospodarstwa domowe są wyłączane z uczestnictwa w systemie finansowym - dotyka je problem wykluczenia finansowego. W dokumentach unijnych, poświęconych tej tematyce, można odnaleźć informacje, że osoby o niskich dochodach, bezrobotni sa grupa społeczną szczególnie wrażliwą na wykluczenie finansowe, czyli doświadczająca problemów w dostępie do produktów i usług finansowych w odpowiedniej dla nich formie. Niski poziom czy wręcz brak dochodu to ważna, ale nie jedyna przyczyna zepchnięcia osób bezrobotnych na margines systemu finansowego, a tym samym skazanie ich na drogą ofertę instytucji pożyczkowych. Wykluczenie społeczne implikuje wykluczenie finansowe, wobec tego promowane przez „Strategię Europa 2020” działania w obszarze inkluzji społecznej są bardzo pożądane w walce $z$ ekskluzją finansowa.

W świetle przedstawionych faktów zrodziła się koncepcja niniejszego artykułu, którego celem stało się zidentyfikowanie czynników determinujących wykluczenie finansowe osób bezrobotnych oraz wskazanie kierunków działań inkluzyjnych, zmierzających do ograniczenia tego ważkiego problemu społeczno-ekonomicznego. Wykorzystane w opracowaniu metody badawcze to model regresji logistycznej i metody opisowe. Dane empi- 
ryczne pochodza z badań własnych przeprowadzonych metoda standaryzowanego wywiadu kwestionariuszowego na próbie 120 osób należących do Jeleniogórskiego Stowarzyszenia Osób Bezrobotnych - odbierających paczki żywnościowe w okresie okołoświątecznym 2013 roku.

\section{Wykluczenie finansowe a osoby bezrobotne}

Definicja wykluczenia finansowego (financial exclusion) została sformułowana w dokumencie Komisji Europejskiej - Financial services provision and prevention of fnancial exclusion. Zgodnie z nia, wykluczenie finansowe oznacza: proces, $w$ którym obywatele dośniadczaja problemów w dostepie do i/ lub koryystaniu z produktów i ustug finansonych na glównym rynku (mainstream market), ketóre sq odpowiednie do ich potrzeb i umo:̇liwiaja im prowadzenie normalnego sycia w spoteczeństwie [Anderloni i in., 2008, s. 9]. W kontekście przytoczonej definicji należy podkreślić, iż jej autorzy odnoszą problem ekskluzji finansowej wyłącznie do formalnie działających, nadzorowanych przez państwo instytucji finansowych, a pomijaja kwestie związane $z$ alternatywnymi pośrednikami finansowymi. Wobec tego osoby, które nie mogą zadłużyć się w banku i w związku z tym korzystają z usług podmiotów sektora shadow banking², zaliczane są do grona wykluczonych finansowo.

Analizowane zjawisko może być rozumiane sensu stricto bądź sensu largo. W pierwszym przypadku odnosi się ono do osób, które nie korzystają z żadnych produktów i usług finansowych - kont osobistych, kart płatniczych, lokat czy kredytów bankowych, a w drugim przypadku dotyczy osób, o których mówi się, że są ubankowione w stopniu ograniczonym, tzn. dysponują rachunkiem bankowym, ale np. bez możliwości skorzystania z kredytu [Anderloni i in., 2008, s. 11].

Warto również zaznaczyć, że w kontekście wykluczonych finansowo członków społeczeństwa można mówić o ekskluzji rzeczywistej i nieuświadomionej. Pierwsza z nich przejawia się tym, że osoby chca, ale nie mogą skorzystać z oferty instytucji finansowych. Na przeszkodzie staje im na przykład wiek - maja za dużo lat, aby nabyć polisolokatę, albo niski dochód, który dyskwalifikuje ich w opinii banku jako potencjalnych kredytobiorców. Z kolei, nieuświadomione wykluczenie finansowe dotyka osoby, które nie uczestniczą w rynku finansowym, gdyż nie odczuwają takiej potrzeby, poddają się samowykluczeniu. W tym świetle za osobę wykluczoną nie można uznać taką, która nie posiada konta osobistego $\mathrm{z}$ własnej woli. W podobnym tonie zjawisko ekskluzji finansowej tłumaczą eksperci Banku Światowego, którzy w raporcie „Finance for All?” napisali, że wykluczenie finansowe objawia się niemożnością skorzystania przez osoby

\footnotetext{
${ }^{2}$ Rada Stabilności Finansowej (FSB) - instytucja, która wspiera i koordynuje działania największych krajowych organów finansowych na szczeblu międzynarodowym - definiuje shadow banking jako: system pośrednictwa keredytowego, który obejmuje jednostki lub działalności pozostajace poza regulowanym systemem bankonym [Shadow Banking..., 2011, s. 1]. Tworza go podmioty: 1) przyjmujące depozyty, które nie sa gwarantowane; 2) transformujące płynność oraz transferujące ryzyko kredytowe; 3) oferujące sekurytyzację, pożyczki papierów wartościowych i transakcje z przyrzeczeniem odkupu.
} 
fizyczne i przedsiębiorców z formalnych usług finansowych z uwagi na cenowe i pozacenowe bariery [Demirgüç-Kunt i in., 2008, s. 27].

Próbę zidentyfikowania osób szczególnie narażonych na wykluczenie finansowe podjął K. C. Chakrabarty [Chakrabarty, 2006, s. 7]. Z jego opracowania wynika, że są to głównie: osoby o niskich dochodach, niepełnosprawni, ludzie starzy i dzieci, kobiety, osoby słabo wykształcone, mniejszości etniczne i bezrobotni. Problem często dotyka także gospodarstw domowych, mających trudności finansowe (nadmierne zadłużenie wskutek nieszczęśliwego wypadku czy utraty pracy). Z uwagi na temat niniejszej pracy dalsze rozważania skoncentrowano na jednej z wymienionych grup społecznych, tj. na ludziach bezrobotnych.

Według przepisów Ustany z dnia 20 kwietnia 2004 r. o promocji zatrudnienia i instytucjach rynku pracy (Dz. U. 2004, Nr 99, poz. 1001, z późn. zm.), bezrobotny: jest osobq niezatrudniona i niewykonujaca innej pracy zarobkowej, zdolna $i$ gotowa do podjecia zatrudnienia w petnym uymiarze czasu pracy obowiazujacym w danym zawodzie lub stu̇bie, (...) zarejestrowana we wlascinym dla miejsca zameldowania statego lub czasowego powiatowym urzedzie pracy oraz poszukujaca zatrudnienia lub innej pracy zarobkowej, jeżeli ukońçyla 18 lat, nie osiagneła wieku emerytalnego. Główny Urząd Statystyczny podał, że w listopadzie 2013 roku ponad 2,1 mln Polaków nie miało pracy, co oznacza, że bezrobotni, zarejestrowani w urzędach pracy, stanowili 13,2\% cywilnej ludności aktywnej zawodowo. Najgorzej sytuacja wyglądała w województwie warmińsko-mazurskim $(21,1 \%)$, a najlepiej w wielkopolskim $(9,5 \%)$. W powiecie jeleniogórskim stopa bezrobocia wyniosła 19,6\%, zaś w samym mieście blisko 9,4\%.

Osoby bezrobotne na co dzień żyją z oszczędności, o ile jeszcze takie posiadają, zasiłków, zapomóg z pomocy społecznej, są na utrzymaniu rodziny, poza tym często dochody czerpią z pracy nierejestrowanej („na czarno”), która może mieć charakter stały lub sezonowy. Brak dochodów lub niemożność ich udokumentowania staje się poważną przeszkodą w otrzymaniu pożyczki bankowej, a tym samym stanowi istotną barierę na drodze do poprawy sytuacji ekonomicznej ubogich gospodarstw domowych. Uniemożliwia zwiększenie dochodów czy ustabilizowanie wydatków, które pozwoliłyby na zmniejszenie presji finansowej, związanej z różnymi nieprzewidzianymi wydarzeniami (np.: nagłą śmiercią członka rodziny, wypadkiem czy choroba). Trudno jednoznacznie określić, czy wykluczenie finansowe jest skutkiem, czy przyczyną zubożenia pewnych grup społecznych. Niskie dochody zamykaja gospodarstwu domowemu drogę do kredytu bankowego z uwagi na niedostateczną zdolność kredytową. W ten sposób wszelkie przejawy przedsiębiorczości, mającej ostatecznie doprowadzić do poprawy jakości życia, kończą się niepowodzeniem. W rezultacie nierówności społeczne tylko się pogłębiają. Powszechnie bowiem wiadomo, że kredyt najłatwiej uzyskać bogatemu, który będzie mógł pomnażać swój majtek korzystając z efektów dźwigni finansowej. Z kolei, ubogi przez wykluczenie go z głównego rynku kredytowego trafia na drogą ofertę niebankowych instytucji pożyczkowych.

Warunkiem podjęcia skutecznych działań, służących ograniczaniu wykluczenia finansowego osób bezrobotnych, jest właściwe rozpoznanie jego determinant. Niewatpliwie, najdonioślejszą z nich jest niski dochód, natomiast do zidentyfikowania pozostałych czynników w niniejszym opracowaniu wykorzystano model regresji logistycznej. 


\section{Determinanty wykluczenia finansowego osób bezrobotnych}

\subsection{Regresja logistyczna - ujęcie teoretyczne}

Regresja to metoda statystyczna, której celem jest badanie zależności pomiędzy zmiennymi niezależnymi (objaśniającymi), zwanymi predyktorami (predictors), a zmienną zależną (objaśniana). Formalnie rzecz ujmując, regresja pozwala estymować warunkową wartość oczekiwana - $[\mathrm{E}(\mathrm{Y} \mid \mathrm{X})]$ zmiennej zależnej dla określonych wartości lub wektora zmiennych niezależnych. W praktyce metoda ta polega na konstrukcji funkcji opisującej, jak zależy wartość oczekiwana zmiennej zależnej od zmiennych niezależnych. Ogólną postać regresji można przedstawić następująco:

gdzie:

$$
E(X \mid Y)=f(X, \beta),
$$

$\mathrm{Y}$ - zmienna zależna,

$\mathrm{X}-\mathrm{zmienne}$ niezależne,

$\mathrm{E}(\mathrm{X} \mid \mathrm{Y})$ - warunkowa wartość oczekiwana $\mathrm{Y}$ przy danej wartości $\mathrm{X}$,

$\beta$ - wektor współczynników regresji,

$\mathrm{f}(\mathrm{X}, \beta)$ - funkcja regresji.

W praktyce badawczej można spotkać się z sytuacjami, gdy zmienna objaśniana przyjmuje wartości 0 - gdy zjawisko nie ma miejsca i 1 - gdy dane zjawisko występuje (np.: konkretne zachowanie, ujawnienie postawy, opinii itd.). Taki dychotomiczny charakter zmiennej zależnej sprawił, że należy sięgnąć po analizy nieliniowe. Modelem regresyjnym stosowanym dla tego typu zmiennych zależnych, jest regresja logistyczna (model logitowy), w tym przypadku dwumianowa. Znana jest ona badaczom od lat siedemdziesiątych XX wieku, a dokładnie od opublikowania przez D. J. Finneya pracy pt.: Probit analysis [Finney, 1971].

Model regresji logistycznej jest oparty na funkcji logistycznej. Przyjmuje ona wartości z przedziału $<0 ; 1>$, gdzie 0 i 1 sa wartościami brzegowymi, osiaganymi $\mathrm{w}+\infty$ i - $\infty$ [Hosmer, Lemeshow, 2000, s. 5-6]. Równanie regresji logistycznej, podobnie jak równanie regresji liniowej, pozwala na obliczenie wartości oczekiwanej zmiennej zależnej. Ponieważ model regresji logistycznej dotyczy binarnych zmiennych zależnych, wartość oczekiwana zmiennej zależnej Y' została zastąpiona wartością warunkowego prawdopodobieństwa, że zmienna zależna $Y$ przyjmie wartość 1 dla zmiennych niezależnych: $\mathrm{X}_{1}, \mathrm{X}_{2}, \ldots, \mathrm{X}_{\mathrm{k}}$. Z własności funkcji logistycznej wynika, że obie te wartości (oczekiwane zmiennej Y' oraz warunkowe prawdopodobieństwo przyjęcia wartości 1) są równe. Stąd model regresji logistycznej można wyrazić równaniem [Kleinbaum, Klein, 2005, s. 7]:

$$
\begin{gathered}
P\left(Y^{\prime}=1 \mid X_{1}, X_{2}, \ldots, X_{k}\right)=\frac{1}{1+e^{\operatorname{logit}(p)},} \\
\operatorname{logit}(p)=\ln \frac{p}{1-p}=\ln (p)-\ln (1-p)=\beta_{0}+\beta_{1} X_{1}+\ldots+\beta_{k} X_{k}, \\
P\left(Y^{\prime}=1 \mid X_{1}, X_{2}, \ldots, X_{k}\right)=\frac{1}{1+e^{-\left(\beta_{0}+\beta_{1} X_{1}+\ldots+\beta_{k} X_{k}\right)},}
\end{gathered}
$$


gdzie:

$P\left(Y^{\prime}=1 \mid X_{1}, X_{2}, \ldots, X_{k}\right)$ - warunkowe prawdopodobieństwo osiagnięcia przez zmienną zależną wartości 1 przy konkretnych wartościach zmiennych: $\mathrm{x}_{1}, \mathrm{x}_{2}, \ldots, \mathrm{x}_{\mathrm{k}}$, $e-$ stała Eulera $=2,71828 \ldots$, baza logarytmu naturalnego,

$\beta_{0}$ - stała regresji dla regresji logistycznej,

$\beta_{i}$ - współczynnik regresji logistycznej dla i-tej zmiennej niezależnej,

$\mathrm{X}_{\mathrm{i}}$ - i-ta zmienna niezależna, $\mathrm{i}=1,2, \ldots, \mathrm{k}$.

Regresja logistyczna bazuje na tzw. prawdopodobieństwie szansy (odds - O), czyli stosunku prawdopodobieństwa, że dane zdarzenie wystapi (p) do prawdopodobieństwa, że dane zdarzenie nie wystapi $(\mathrm{q}=1-\mathrm{p})$. Warto zwrócić uwagę również na fakt, iż wspó1czynniki regresji logistycznej są obliczane według metody największej wiarygodności, a nie, jak ma to miejsce w przypadku regresji liniowej, gdzie szacowane są za pomocą metody najmniejszych kwadratów.

Testowanie modelu regresji logistycznej odbywa się w trzech obszarach. Pierwszym jest testowanie słuszności całej teorii, a więc wszystkich przypuszczeń razem wziętych. Sprowadza się ono do zbadania jakości dopasowania modelu, czyli odpowiedzi na pytanie, w jakim stopniu dobrze wyjaśnia on zmienną zależna. Drugim obszarem jest testowanie poszczególnych hipotez, polegające na identyfikacji istotności statystycznej przewidzianego wpływu predyktorów na zmienną zależną. Trzecim obszarem weryfikacji jest analiza mocy predykcyjnej teorii, czyli poznania, jak dobrze model klasyfikuje obserwacje.

Weryfikacja jakości dopasowania modelu polega na przeprowadzeniu czterech testów: współliniowości (collinearity), ilorazu wiarygodności, Hosmera-Lemeshowa (test H-L, goodness-of-fit test), [szerzej: Hosmer, Lemeshow, 1980, s. 1043-1069] oraz zbieżności. Odnosząc się do ostatniego z wymienionych testów należy nadmienić, że ze względu na wykorzystywaną metodę szacowania współczynników regresji logistycznej znalazł tu zastosowanie współczynnik determinacji, określany mianem pseudo- $\mathrm{R}^{2}$, zwany od nazwiska jego twórcy R² McFaddena [McFadden, 1974, s. 105-142], a właściwie jego zmodyfikowana wersja - $\mathrm{R}^{2}$ Nagelkerke'a.

Po analizie jakości dopasowania modelu można przejść do weryfikacji poszczególnych hipotez. W regresji logistycznej stosuje się w tym celu dwie metody: test Walda $\left(Z_{\mathrm{w}}\right)$ i iloraz szans (OR - odds ratio). Pierwsza analizuje istotność statystyczną wpływu predyktorów na zmienną zależną i polega najpierw na oszacowaniu współczynnika regresji $\beta$ oraz wartości błędu standardowego (S.E. - standard error) dla danej zmiennej niezależnej $\mathrm{X}$, a następnie obliczeniu na ich podstawie statystyki Walda (5), która ma rozkład chi-kwadrat, dlatego otrzymaną jej wartość dla X należy porównać z odczytaną z tablic rozkładu wartością krytyczną dla zadanego $\alpha$ :

$$
Z_{w}=\frac{\beta}{S \cdot E \cdot(\beta)}
$$

Natomiast iloraz szans informuje, jak zmienia się szansa zajścia zdarzenia zawartego w zmiennej zależnej (wartość 1) w przypadku wzrostu danej zmiennej niezależnej o jedną jednostkę. Oblicza się go w następujący sposób: 


$$
O R=\frac{O(A)}{O(B)}=\frac{P(A)}{1-P(A)} \div \frac{P(B)}{1-P(B)^{\prime}}
$$

gdzie:

$\mathrm{P}(\mathrm{A})$ - prawdopodobieństwo zajścia zdarzenia (wartość $1 \mathrm{w}$ zmiennej zależnej) w klasie obserwacji A (wartość 1 zmiennej niezależnej);

$\mathrm{P}(\mathrm{B})$ - prawdopodobieństwo zajścia zdarzenia (wartość $1 \mathrm{w}$ zmiennej zależnej) w klasie obserwacji B (wartość 0 zmiennej niezależnej).

Przyjmuje się, że jeżeli:

- $\quad$ OR $>1$, to czynnik zawarty w X ma stymulujący wpływ na wystapienie danego zdarzenia. Wtedy OR informuje, o ile wzrasta szansa na wystąpienie wartości $1 \mathrm{w}$ zmiennej zależnej, gdy predyktor wzrasta o jedną jednostkę;

- $\quad$ OR $<1$, to czynnik zawarty w X negatywnie wpływa na wystapienie danego zdarzenia. Wtedy OR informuje, o ile spada szansa na wystąpienie wartości $1 \mathrm{w}$ zmiennej zależnej, gdy predyktor wzrasta o jedną jednostkę;

- $\quad \mathrm{OR}=1$, to czynnik zawarty w X nie ma wpływu na wystapienie danego zdarzenia.

Podczas analizy ilorazu szans wyznacza się również dla każdego predyktora tzw. przedział ufności (CI - Confidence Interval). Jest to przedział liczbowy, który z określonym z góry przez badacza prawdopodobieństwem 1- $\alpha$, zwanym poziomem ufności, będzie zawierał nieznaną wartość szacowanego parametru populacji.

Trzecim wymiarem weryfikacji jakości modelu jest analiza mocy predykcyjnej teorii, czyli poznania, jak dobrze klasyfikuje on obserwacje. Weryfikacja możliwości predykcyjnych modelu (teorii) sprowadza się do dokonania dwóch testów na podstawie tabeli klasyfikacyjnej i krzywej ROC. W przypadku regresji logistycznej standardowa tabela klasyfikacyjna jest macierzą kwadratową o wymiarach 2x2, w której kolumny zawierają klasy decyzji prognozowane przez model, a wiersze klasy decyzji zaobserwowane realnie (tabela 1.).

TABELA 1.

Przykład tabeli klasyfikacyjnej

\begin{tabular}{|c|c|c|c|}
\hline \multicolumn{2}{|c|}{ Klasyfikacja } & \multicolumn{2}{|c|}{ Decyzje prognozowane } \\
\hline & & Pozytywna & Negatywna \\
\hline \multirow[t]{2}{*}{$\begin{array}{l}\text { Decyzje } \\
\text { zaobserwowane }\end{array}$} & Pozytywna & $\begin{array}{l}\text { Prawdziwie pozytywna (TP }- \text { True } \\
\text { Positive) }\end{array}$ & Fałszywie negatywna (FN - False Negative) \\
\hline & Negatywna & $\begin{array}{l}\text { Fałszywie pozytywna (FP - False } \\
\text { Positive) }\end{array}$ & $\begin{array}{l}\text { Prawdziwie negatywna ( } \mathrm{TN}-\text { True } \mathrm{Ne} \text { - } \\
\text { gative) }\end{array}$ \\
\hline
\end{tabular}

Źródło: [Hosmer, Lemeshow, 2000, s. 160].

Istotnym elementem analizy tabeli jest procentowe ustalenie trzech wielkości: trafności (ACC), czułości (C - sensitivity) i specyficzności ( $\mathrm{S}$ - specificity). Pierwsza określa, jaki procent w całej liczbie obserwacji stanowia przypadki poprawnie pozytywnie i negatywnie sklasyfikowane przez model i wyraża się wzorem:

$$
A C C=100\left[\frac{T P+T N}{T P+T N+F P+F N}\right] \% .
$$


Czułość informuje o procentowym udziale przypadków poprawnie i pozytywnie sklasyfikowanych przez model we wszystkich przypadkach pozytywnie zaobserwowanych i przybiera postać:

$$
C=100\left[\frac{T P}{T P+F N}\right] \%
$$

Natomiast specyficzność określa procentowy udział przypadków poprawnie, lecz negatywnie przewidzianych przez model w ogólnej liczbie przypadków negatywnie zaobserwowanych:

$$
S=100\left[\frac{T N}{F P+T N}\right] \% .
$$

Powyższe wskaźniki są wyliczane w tzw. punkcie odcięcia prawdopodobieństwa przewidywanego i oznajmuje, w jakim stopniu model prawidłowo przewiduje wartości zmiennej zależnej.

Analiza ROC (Receiver Operating Characteristics) polega na konstrukcji krzywej ilustrującej związek między dwoma współczynnikami klasyfikacyjnymi: czułością i specyficznościa. Jeśli wykres pokrywa się z przekątną $(y=x)$, to oznacza, że model nic nie wnosi do analizy, gdyż dokonane przez niego klasyfikacje są tak samo dobre, jak decyzja losowa. Im bardziej krzywa zbliża się do lewej ćwiartki wykresu, tym lepsze są wskazania modelu. Wysoki poziom czułości (bliski 1) określa, że model prawidłowo rozpoznaje dane przypadki, podczas gdy niska wartość 1-S świadczy o tym, że niewiele przypadków negatywnych klasyfikuje jako pozytywne.

Jednak najważniejszą własnością interpretacyjną ROC jest pole powierzchni znajdujące się pod krzywą, oznaczane jako AUC (Area Under Curve). Przyjmuje ono wartości w przedziale $[0,1]$ i dowodzi jakości klasyfikacyjnej modelu. Im wyższy jest wskaźnik AUC, tym lepszy model. Przyjmuje się, że jeśli AUC osiąnie wartość 0,7, to klasyfikację należy uznać za akceptowalną, a jeżeli przekroczy 0,8 za bardzo dobrą [Hosmer, Lemeshow, 2000, s. 162].

\subsection{Metodologia badań}

Sformułowany na wstępie opracowania cel zdeterminował wybór zmiennych do modelu ekonometrycznego. Zmienna zależna Y (osoba wykluczona finansowo w rozumieniu przedstawionym w podrozdziale trzecim, gdzie 1 - sukces, 0 - porażka) ma charakter dychotomiczny. Jeśli chodzi o kandydatki na zmienne objaśniające, to wytypowano je na podstawie ogólnej wiedzy z zakresu finansów osobistych, a także dotychczasowych badań i obserwacji o podobnej tematyce, prowadzonych przez autora w obszarze wykluczenia finansowego. Na kolejnym etapie metody badawczej przystapiono do gromadzenia danych statystycznych. Zadanie to zrealizowano stosując metodę standaryzowanego wywiadu kwestionariuszowego (patrz załącznik artykułu) przeprowadzonego osobiście przez autora na próbie 120 osób należących do Jeleniogórskiego Stowarzyszenia Osób Bezrobotnych - odbierających paczki żywnościowe w okresie okołoświątecznym 2013 roku. Po wyeliminowaniu odpowiedzi sprzecznych i niepełnych, 
ostatecznie do dalszej analizy zostały zakwalifikowane 104 poprawnie wypełnione kwestionariusze.

Kobiety stanowiły 56,7\% ankietowanych, podczas gdy mężczyźni 43,3\%. Jeśli chodzi o wiek, to najwięcej bezrobotnych mieściło się w przedziale od 35 do 44 lat $(32 \%)$, dokładna struktura wieku respondentów została przedstawiona na rysunku 1 . Trzeci z parametrów, opisujących próbę badawcza, tj. wykształcenie, wskazuje, iż kwestionariusz wypełniło 13 osób z wykształceniem podstawowym, 39 z zasadniczym zawodowym, 44 ze średnim oraz 8 z policealnym i wyższym. Wszyscy respondenci byli mieszkańcami Jeleniej Góry.

RYSUNEK 1.

\section{Struktura badanej populacji ze względu na wiek}

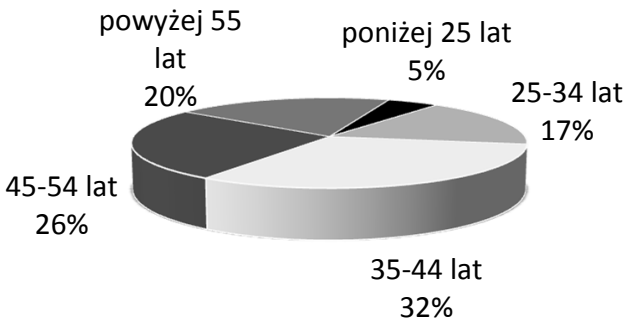

Źródło: opracowanie własne.

Na pytanie „Czy posiada Pan/Pani rachunek oszczędnościowo-rozliczeniowy w banku lub Spółdzielczej Kasie Oszczędnościowo-Kredytowej?” pozytywnie odpowiedziało 80 osób, tj. 76,9\% respondentów. Zatem, konta osobistego nie posiadało 24 ankietowanych, ti. 23,1\% ogółu. Okazało się, że właściciele ROR-ów korzystali najczęściej z oferty: Banku Zachodniego WBK SA - 30 osób (37,5\%), Pekao SA - 14 osób (17,5\%), PKO BP SA - 13 osób (16,25\%), BGŻ SA - 11 osób (13,75\%), SKOK - 8 osób (10\%), inne -4 osoby $(5 \%)$. Z kolei, bezrobotni, deklarujący nieposiadanie konta osobistego, byli pytani o przyczynę takiego stanu rzeczy, i tak $100 \%$ z nich wskazało na brak zainteresowania posiadaniem tego produktu finansowego.

Odpowiedzi twierdzącej na 2. pytanie - „Czy posiada Pan/Pani kredyt/pożyczkę w banku lub SKOK-u?" udzieliło 10 osób (9,6\% badanych), w tym 2 respondentów było zadłużonych w banku, a 8 w SKOK-u. Zdecydowana większość - 90,4\% tj. 94 bezrobotnych, nie zawarła umowy pożyczkowej ani z bankiem, ani ze SKOK-iem. Grupę tę zapytano o przyczyny nieposiadania pożyczki bankowej i, jak okazało się, 21 osób otrzymało odmowną decyzję w banku, 12 respondentów nawet się o nią nie ubiegało, gdyż stwierdziło, że nie dostaną pożyczki ze względu na brak stałych dochodów, natomiast pozostali, tj. 61 osób, zadeklarowało brak chęci bycia pożyczkobiorca.

Zdecydowana większość respondentów $(71 ; 68,3 \%)$ nie posiadała zadłużenia w niebankowej instytucji finansowej. Pozostali, to jest 33 osoby, najczęściej korzystali z oferty następujących podmiotów: Provident - 18 osób (54,6\%), Pośrednictwo Finansowe 
„Kredyty-Chwilówki” - 6 osób (18,2\%), Bocian Pożyczki - 3 osoby (9,1\%), Wonga.com -2 osoby (6,1\%), inne -4 osoby $(12 \%)$.

Kolejne pytanie miało określić stosunek respondentów do zadłużania się, czyli skłonność do zaciągania pożyczek. Uzyskane wyniki zestawiono w tabeli 2.

TABELA 2.

Odpowiedzi na pytanie: „Proszę określić swój stosunek do zadłużenia (skłonność do zaciagania pożyczek)"

\begin{tabular}{|l|c|c|}
\hline \multicolumn{1}{|c|}{ Wariant odpowiedzi } & Liczba odpowiedzi & Odsetek \\
\hline Nie mam pożyczek i wcale nie zamierzam zadłużać się. & 35 & $33,6 \%$ \\
Mam pożyczkę, ale planuję jak najszybciej zmniejszyć zadłużenie. & 15 & $14.4 \%$ \\
Nie mam pożyczek, ale planuję zadłużyć się. & 24 & $23,1 \%$ \\
Mam pożyczkę i planuję utrzymać poziom zadłużenia na dotychczaso- & 26 & $25,0 \%$ \\
wym poziomie. & 4 & $3,9 \%$ \\
Mam pożyczkę i nadal planuję zwiększać zadłużenie. & 104 & $100 \%$ \\
\hline RAZEM &
\end{tabular}

Źródło: opracowanie własne.

W pytaniu szóstym, które brzmiało - „Czy ma Pan/Pani problemy z bieżącym regulowaniem swoich zobowiązań?” - 28 osób (27\% respondentów) odpowiedziało, że często ich doświadcza, kolejne 45 osób (43\% respondentów) stwierdziło, że zdarzają się im problemy tego typu raz, dwa razy do roku, natomiast 31 osób (30\% respondentów) zadeklarowało brak trudności związanych z płynnością finansową.

W ostatnim pytaniu ankiety osoby zostały poproszone o ustosunkowanie się do pięciu stwierdzeń. Otrzymane odpowiedzi przedstawiono w tabeli 3.

TABELA 3.

Odpowiedzi na pytanie: „Czy zgadza się Pan/Pani ze stwierdzeniem?”

\begin{tabular}{|c|c|c|c|c|c|c|c|c|}
\hline \multirow{2}{*}{ Treść stwierdzenia } & \multicolumn{2}{|c|}{ Tak } & \multicolumn{2}{|c|}{ Raczej tak } & \multicolumn{2}{|c|}{ Raczej nie } & \multicolumn{2}{|c|}{ Nie } \\
\hline & $\mathrm{n}$ & $(\%)$ & $\mathrm{n}$ & $(\%)$ & $\mathbf{n}$ & $(\%)$ & $\mathbf{n}$ & $(\%)$ \\
\hline $\begin{array}{l}\text { Przepisy prawa regulują maksymalną wysokość od- } \\
\text { setek, zatem całkowity koszt pożyczki jest znany. }\end{array}$ & 13 & 12,5 & 46 & 44,2 & 24 & 23,1 & 21 & 20,2 \\
\hline $\begin{array}{l}\text { Od momentu podpisania umowy o kredyt konsu- } \\
\text { mencki nie można się z niej już wycofać. }\end{array}$ & 21 & 20,2 & 32 & 30,8 & 17 & 16,3 & 34 & 32,7 \\
\hline $\begin{array}{l}\text { Atrakcyjnym dla klienta rozwiązaniem są kredyty } 0 \% \\
\text { oferowane w sklepach, gdyż nic nie kosztują. }\end{array}$ & 23 & 22,1 & 22 & 21,2 & 35 & 33,7 & 24 & 23,0 \\
\hline $\begin{array}{l}\text { Osoba, która miała w przeszłości problemy ze spła- } \\
\text { tą kredytu i jest uwidoczniona w bazie BIK, nie ma } \\
\text { już szansy na kredyt w banku. }\end{array}$ & 68 & 65,4 & 21 & 20,2 & 8 & 7,7 & 7 & 6,7 \\
\hline $\begin{array}{l}\text { Oprocentowanie pożyczki udzielonej przez insty- } \\
\text { tucję niebankową może wynieść } 500 \% \text { p.a. }\end{array}$ & 36 & 34,6 & 29 & 27,9 & 20 & 19,2 & 19 & 18,3 \\
\hline
\end{tabular}

Źródło: opracowanie własne.

Zmienną zależną modelu (Y - osoba wykluczona finansowo) zakodowano na podstawie odpowiedzi udzielonych przez ankietowanych na cztery pytania $(1,1 \mathrm{~B}, 2,2 \mathrm{~B})$ dotyczące posiadania bądź nieposiadania konta osobistego i pożyczki, a także deklaracji re- 
spondentów związanych z chęcią bądź niechęcią korzystania z tego rodzaju produktów finansowych. Miało to na celu zidentyfikowanie osób, które nie posiadaja ROR-u, ale jednocześnie chciałyby go mieć i (suma) osób, które nie mogły zaciagnąć pożyczki bankowej, ale chciałyby to uczynić. Respondenci, przynależący do tej grupy, podlegali rzeczywistemu wykluczeniu finansowemu, a nie samowykluczeniu. W badanej populacji 23,1\% osób zadeklarowało fakt nieposiadania konta osobistego (dla porównania wskaźnik ubankowienia dla Polski na koniec 2011 roku wynosił 70,19\%, czyli ROR-u nie miało 29,81\% Polaków [World Bank eAtlas..., 2013]). Wszyscy ankietowani jako przyczynę tego stanu rzeczy wskazali brak potrzeby, a wręcz zbyteczne, w ich przekonaniu, dodatkowe koszty obciążające budżet domowy. Pozostali oni zatem poza obszarem niniejszej analizy.

Z produktów pożyczkowych korzystało około $45 \%$ ankietowanych bezrobotnych. Zaledwie kilka osób spłacało długi względem banku, które powstały jeszcze w okresie zatrudnienia, a zdecydowana większość była klientami instytucji niebankowych. Ci ostatni wpisali się w profil osoby wykluczonej finansowo, tzn. takiej, która chce korzystać z produktów i usług bankowych, nawet kosztem gorszych warunków cenowych, ale nie ma takiej możliwości. Zdana była więc na ofertę sektora instytucji pożyczkowych, wśród których prym wiedzie Provident i Pośrednictwo Finansowe „Kredyty-Chwilówki” Sp. z o.o. W tym kontekście postawiono pytanie badawcze - jakie czynniki, poza niskimi dochodami, sprzyjają wykluczeniu finansowemu osób bezrobotnych.

Do przeprowadzenia analizy wytypowano kilka zmiennych niezależnych o charakterze: demograficznym, społeczno-ekonomicznym i psychograficznym. Po zweryfikowaniu ich stopnia zmienności (współczynnik zmienności $\mathrm{V}_{\mathrm{x}}$ wynosił powyżej $30 \%$ ) przystąpiono do selekcji kandydatek na zmienne objaśniające. Ostatecznie do dalszych badań przyjęto cztery zmienne nieparametryczne, wielokategorialne, uporządkowane (tabela 4.), które okazały się najsilniej powiązane ze zmienną objaśnianą Y i jednocześnie najsłabiej powiązane między sobą. W badaniu istotności korelacji posłużono się metodami C-Pearsona, V-Cramera.

TABELA 4.

Zmienne zależne uwzględnione w modelu logistycznym

\begin{tabular}{|c|c|c|}
\hline \multicolumn{2}{|r|}{ Zmienna } & Kategorie \\
\hline & - awersja do zadłużania się & $\begin{array}{l}\text { 3- osoba wykazuje bardzo silną awersję do zadłużania się; } 2 \text { - } \\
\text { osoba wykazuje silną awersję do zadłużania się; } 1 \text { - osoba wyka- } \\
\text { zuje słabą awersję do zadłużania się; } 0 \text { - osoba nie wykazuje } \\
\text { awersji do zadłużania się }\end{array}$ \\
\hline $\mathrm{X}_{2}$ & $\begin{array}{l}\text { - problemy z zarządzaniem płynnością } \\
\text { budżetu gospodarstwa domowego }\end{array}$ & $\begin{array}{l}2 \text { - częste problemy finansowe; } 1 \text { - sporadycznie problemy finan- } \\
\text { sowe; } 0 \text { - brak problemów finansowych }\end{array}$ \\
\hline $\mathrm{X}_{3}$ & - świadomość finansowa & $\begin{array}{l}3 \text { - wysoki poziom świadomości finansowej; } 2 \text { - przeciętny po- } \\
\text { ziom świadomości finansowej; } 1 \text { - niski poziom świadomości fi- } \\
\text { nansowej; } 0 \text { - bardzo niski poziom świadomości finansowej }\end{array}$ \\
\hline & - wykształcenie & $\begin{array}{l}1 \text { - podstawowe; } 2 \text { - zasadnicze zawodowe; } 3 \text { - średnie; } 4 \text { - poli- } \\
\text { cealne, wyższe }\end{array}$ \\
\hline
\end{tabular}

Źródło: opracowanie własne.

Pierwsza ze zmiennych objaśniających $\left(\mathrm{X}_{1}\right)$ pokazuje stosunek do zadłużania się. Awersja, zgodnie ze słownikiem języka polskiego, oznacza silne uczucie niechęci do czegoś, 
w tym przypadku do zadłużania się. Ponadto, awersja jest uznawana jako antonim terminu skłonność. Zmienną zakodowano na podstawie odpowiedzi na czwarte pytanie ankiety. Respondent, który zadeklarował, że nie posiada pożyczek i nie planuje ich zaciagać w przyszłości - pierwszy wariant odpowiedzi - wykazuje bardzo silną awersję do zadłużania się (33,6\% wskazań). Silną awersją do zadłużania się cechują się osoby, które wskazały drugi i trzeci wariant odpowiedzi, z kolei o słabej awersji można mówić w odniesieniu do ankietowanych decydujących się na odpowiedź „Mam pożyczkę i planuję utrzymać poziom zadłużenia na dotychczasowym poziomie". Wreszcie osoby, które mają i planują nadal zwiększać swoje zadłużenie (4\% respondentów), charakteryzują się brakiem awersji do zadłużania się.

Druga zmienna objaśniająca $\left(\mathrm{X}_{2}\right)$ dotyczy problemów z płynnością pojawiających się w związku z zarządzaniem budżetem gospodarstwa domowego. Przejawiać się one moga brakiem wystarczających dochodów pozwalających na terminowe regulowanie rachunków za czynsz, energię elektryczną czy inne media, bądź też na spłacanie rat zaciagniętych wcześniej pożyczek. W takiej sytuacji gospodarstwa domowe najczęściej pożyczają środki pieniężne od rodziny i znajomych, spóźniają się z zapłatą i ponoszą z tego tytułu kary lub decydują się na zaciągnięcie wysoko oprocentowanej pożyczki w firmie pożyczkowej. Jeśli takie problemy finansowe pojawiają się rzadko, to nie niosą ze sobą groźnych konsekwencji. Gorzej, jeżeli mają charakter nagminny i dochodzi do sytuacji zaciagania coraz droższych pożyczek na spłatę wymagalnych długów, bowiem bardzo często oznacza to początek spirali zadłużenia. Częste kłopoty finansowe w szóstym pytaniu ankiety zadeklarowało $27 \%$ respondentów, podczas gdy tylko około $30 \%$ z nich nie stwierdziło żadnych problemów z zarządzaniem płynnością budżetu gospodarstwa domowego.

Kolejna zmienna objaśniająca to świadomość finansowa $\left(\mathrm{X}_{3}\right)$. Badaniem jej poziomu wśród Polaków ogółem i w różnych przekrojach zawodowych zajmowały się m.in.: D. Maison z Uniwersytetu Warszawskiego [Maison, 2013], M. Iwanicz-Drozdowska, z SGH [Iwanicz-Drozdowska, 2011]. Regularnie wyniki na temat świadomości finansowej analizowanej w skali międzynarodowej, publikuje OECD. Na potrzeby niniejszego modelu w siódmym pytaniu ankiety ankietowanym zostały przedstawione różne stwierdzenia, a ich zadaniem było określenie, czy są one: prawdziwe, raczej prawdziwe, raczej fałszywe czy fałszywe. Udzielone odpowiedzi pozwoliły zakodować zmienną $\mathrm{X}_{3}$. Za każdą odpowiedź można było uzyskać od 0 do 3 punktów, czyli za wszystkie poprawne odpowiedzi można było zdobyć maksymalnie 15 punktów. Następnie stworzono cztery równe kategorie odpowiadające danym poziomom świadomości finansowej respondentów i tak np. osoba przypisana do kategorii numer 3 musiała w teście zdobyć od 12 do 15 punktów.

Ze zmiennych o charakterze społeczno-demograficznym tylko poziom wykształcenia respondentów okazał się istotny statystycznie i dlatego stał się ostatnią zmienną objaśniającą modelu $\left(\mathrm{X}_{4}\right)$.

Współczynniki korelacji zmiennej $\mathrm{Y}$ modelu względem zmiennych: $\mathrm{X}_{1}, \mathrm{X}_{2}, \mathrm{X}_{3}$ i $\mathrm{X}_{4}$, obliczone metoda C-Pearsona z wykorzystaniem Statystycznego Oprogramowania Obliczeniowego PQStat, jak już wspomniano, można uznać za wysokie, a nawet bardzo wysokie, bowiem kształtują się od 0,5 do 0,7. Natomiast wartości współczynników korelacji między zmiennymi: $\mathrm{X}_{1}, \mathrm{X}_{2}, \mathrm{X}_{3}$ i $\mathrm{X}_{4}$ nie przekraczają wartości 0,270 , co uprawnia do stwierdzenia, że są słabe, szczegółowe wyniki zestawiono w macierzy: 


$\left[\begin{array}{cccc}1,00 & 0,221 & 0,270 & 0,251 \\ 0,221 & 1 & 0,176 & 0,206 \\ 0,270 & 0,176 & 1 & 0,255 \\ 0,251 & 0,206 & 0,255 & 1\end{array}\right]$

Kolejnym etapem budowy modelu regresji logistycznej jest postawienie hipotez badawczych, określających wpływ poszczególnych czynników (zmiennych niezależnych) na wykluczenie finansowe bezrobotnych (zmienna zależna). Są nimi:

- $\mathrm{H}_{1}$ : Prawdopodobieństwo wykluczenia finansowego zależy od stopnia awersji do zadłużania się;

- $\mathrm{H}_{2}$ : Prawdopodobieństwo wykluczenia finansowego zależy od skali problemów z zarządzaniem płynnością budżetu gospodarstwa domowego;

- $\quad \mathrm{H}_{3}$ : Prawdopodobieństwo wykluczenia finansowego zależy od poziomu świadomości finansowej;

- $\mathrm{H}_{4}$ : Prawdopodobieństwo wykluczenia finansowego zależy od poziomu wykształcenia.

Następnie należy postawić hipotezy zerowe, stanowiące negację powyższych przypuszczeń. Zakładają one brak istotnego wpływu: $\mathrm{X}_{1}, \mathrm{X}_{2}, \mathrm{X}_{3}, \mathrm{X}_{4}$ na zmienną $\mathrm{Y}$.

\subsection{Regresja logistyczna - wyniki badań}

Model regresji logistycznej powinno się poddać weryfikacji w trzech obszarach: jakości dopasowania, istotności poszczególnych hipotez i mocy predykcyjnej teorii. Rozpoczynając od obszaru pierwszego, trzeba najpierw dokonać testu współliniowości. Krzyżowe korelacje między predykatorami wskazują jednoznacznie na słabe zależności, w żadnym przypadku nie przekraczaja one granicy 0 ,2. Ponadto, wskaźnik VIF (variance inflation factor) dla wszystkich zmiennych jest poniżej krytycznej wartości $(\mathrm{VIF}<3)$. Wobec tego można wykluczyć niepożądane zjawisko wspólliniowości.

Wyniki trzech kolejnych testów jakości dopasowania modelu regresji logistycznej przedstawiono w tabeli 5 .

TABELA 5.

\section{Współczynniki jakości dopasowania modelu}

\begin{tabular}{|l|l|}
\hline \multicolumn{1}{|c|}{ Test } & \multicolumn{1}{c|}{ Współczynnik } \\
\hline \multirow{2}{*}{ Test ilorazu wiarygodności } & $-2 \log (\mathrm{L})=64,47$ \\
\cline { 2 - 2 } & $\chi^{2}=65,49(\mathrm{df}=4 ; \mathrm{p}=<0,000001)$ \\
\hline Test Hosmera-Lemenshowa & $\chi^{2}=2,49(\mathrm{df}=8 ; \mathrm{p}=0,96)$ \\
\hline $\mathrm{R}^{2}$ Nagelkerke & 0,65 \\
\hline
\end{tabular}

Źródło: opracowanie własne z wykorzystaniem Statystycznego Oprogramowania Obliczeniowego PQStat.

Jeśli chodzi o wartość statystyki $\mathrm{G}$ dla dewiancji budowanego modelu, to wynosi ona 65,45, podczas gdy $\chi_{\text {krytyczne }}^{2}$ dla $\alpha=0,01$ i czterech stopni swobody równa się 13,277, co dowodzi, że wynik testu jest istotny statystycznie. Można zatem odrzucić $\mathrm{H}_{0}$ i przyjąć, że model jest zdecydowanie lepszy od losowego. Wynik drugiego testu - Hosmera- 
Lemeshowa - równiė̇ potwierdza dobre dopasowanie modelu, ponieważ nie jest on istotny na poziomie 0,01 , gdyż $\chi_{k r y t y c z n e}^{2}$ dla $\alpha$ i ośmiu stopni swobody wynosi 20,09 a w analizowanym przypadku $\chi_{\text {otrzymane }}^{2}<\chi_{\text {krytyczne }}^{2}(2,49<20,09)$ dla $\mathrm{p}>\alpha$ $(0,96>0,01)$. Natomiast współczynnik determinacji R ${ }^{2}$ Nagelkerke pokazuje, że 65\% wariancji zmiennej zależnej jest wyjaśniana przez wariancję zmiennych niezależnych. Oznacza on bowiem, że istnieje jeszcze pewien nieduży procent wariancji, który wyjaśniają inne predyktory nie ujęte w modelu. Reasumując, teoria zdała test jakości dopasowania, dlatego że jest lepsza od modelu losowego i podaje nowe wyjaśnienie zachowania zmiennej zależnej.

Po teście jakości dopasowania modelu można przejść do weryfikacji hipotez. Tabela 6 przedstawia wyniki regresji logistycznej.

TABELA 6.

Wyniki regresji logistycznej

\begin{tabular}{|l|r|r|r|r|r|r|r|}
\hline Wyszczególnienie & $\begin{array}{r}\text { Współczyn- } \\
\text { nik } \boldsymbol{\beta}\end{array}$ & Błąd $\boldsymbol{\beta}$ & $\mathbf{- 9 9 \%} \mathbf{C I}$ & $\mathbf{+ 9 9 \% C I}$ & Wald stat. & Wartość $\mathbf{p}$ & \multicolumn{1}{c|}{$\begin{array}{c}\text { Iloraz } \\
\text { szans }\end{array}$} \\
\hline wyraz wolny & 9,7025 & 2,4316 & 3,4392 & 15,9658 & 15,9219 & 0,00007 & 16358,72 \\
$\mathrm{X}_{1}$ & $-1,2435$ & 0,3300 & $-2,0935$ & $-0,3935$ & 14,1987 & 0,00016 & 0,2884 \\
$\mathrm{X}_{2}$ & 1,8470 & 0,5314 & 0,4782 & 3,2157 & 12,0814 & 0,00051 & 6,3406 \\
$\mathrm{X}_{3}$ & $-1,6392$ & 0,4115 & $-2,6992$ & $-0,5792$ & 15,8665 & 0,00007 & 0,1941 \\
$\mathrm{X}_{4}$ & $-1,3958$ & 0,5070 & $-2,7016$ & $-0,0899$ & 7,5802 & 0,00590 & 0,2476 \\
\hline
\end{tabular}

Źródło: opracowanie własne z wykorzystaniem Statystycznego Oprogramowania Obliczeniowego PQStat.

Równanie regresji logistycznej przyjmuje następującą postać:

$$
P\left(Y^{\prime}=1 \mid X_{1}, X_{2}, X_{3}, X_{4}\right)=\frac{1}{1+e^{-\left(9,7025-1,2435 X_{1}+1,8470 X_{2}-1,6392 X_{3}-1,3958 X_{4}\right)}} .
$$

Zmienna $\mathrm{X}_{1}$ - awersja do zadłużania się jest istotna statystycznie na bardzo wysokim poziomie $(\mathrm{p}<0,001)$, co pozwala odrzucić $\mathrm{H}_{0}$ o braku wpływu tego predyktora na zmienną zależną i przyjąć za prawdziwą hipotezę alternatywną $\mathrm{H}_{1}\left(\chi_{\text {krytyczne dla } \alpha=0,01}^{2}\right.$ i df $=1$ jest równe 6,635, podczas gdy statystyka Walda w modelu osiagnęła wartość 14,1987). Iloraz szans dla analizowanej zmiennej wynosi 0,2884 (por.: rysunek 2.), czyli jest mniejszy od 1, świadcząc o destymulującym, ujemnym wpływie awersji do zadłużania się na wykluczenie finansowe jednostki. Świadczy to o tym, że osoby, które obawiają się zadłużać, unikają kredytów i pożyczek, są mniej podatne na ekskluzję. Dokładnie wartość OR można zinterpretować następująco: prawdopodobieństwo wykluczenia finansowego osób bezrobotnych spada blisko trzykrotnie, gdy stopień ich awersji do zadłużania się wzrasta o jeden poziom. Przedział ufności (+/-99\%) omawianej zmiennej wynosi od 0,1233 do 0,6747. 
RYSUNEK 2.

\section{Iloraz szans}

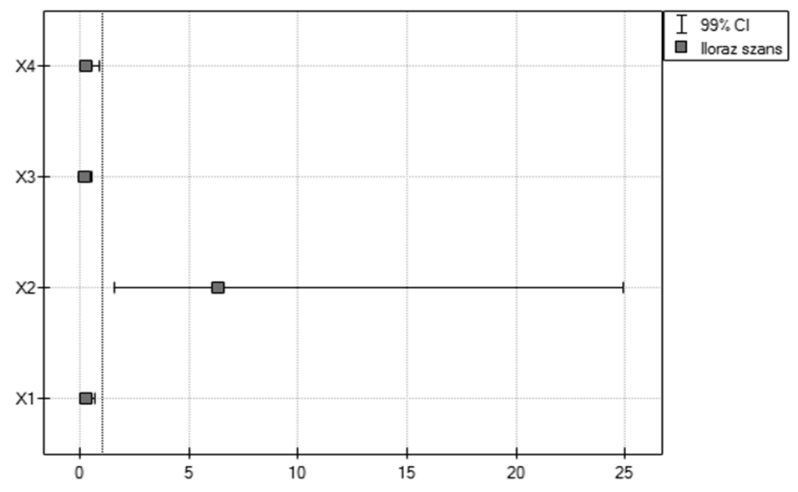

Źródło: opracowanie własne z wykorzystaniem Statystycznego Oprogramowania Obliczeniowego PQStat.

Kolejna zmienna $\mathrm{X}_{2}$ (problemy z zarządzaniem płynnością budżetu gospodarstwa domowego) jest istotna statystycznie również na wysokim poziomie $(\mathrm{p}<0,001)$, co pozwala odrzucić $\mathrm{H}_{0}$ o braku jej wpływu na zmienną zależną i przyjąć za prawdziwą hipotezę alternatywną $\mathrm{H}_{2}\left(\chi_{\text {krytyczne }}^{2} \mathrm{dla} \alpha=0,01 \mathrm{i} \mathrm{df}=1\right.$ jest równe 6,635, podczas gdy statystyka Walda w tym przypadku osiagnęła wartość 12,0814). Iloraz szans dla analizowanej zmiennej wynosi 6,3406 , czyli jest większy od 1, świadcząc o stymulującym i dodatnim wpływie predykatora na wykluczenie finansowe jednostki. Oznacza to, że osoby odczuwające częste problemy finansowe, którym okresowo brakuje środków pieniężnych na bieżące wydatki, sa bardziej podatne na wykluczenie finansowe. Zatem, wartość OR można zinterpretować następująco: prawdopodobieństwo wystąienia ekskluzji finansowej wzrasta ponad sześciokrotnie, gdy stopień problemów z zarządzaniem płynnością budżetu gospodarstwa domowego wzrasta o jeden poziom. Przedział ufności omawianej zmiennej wynosi od 1,6132 do 24,9210.

Zmienna $\mathrm{X}_{3}$ (świadomość finansowa), podobnie jak dwie poprzednie zmienne objaśniające, jest istotna na bardzo wysokim poziomie $(\mathrm{p}<0,0001)$, co pozwala odrzucić $\mathrm{H}_{0}$ o braku wpływu tego predyktora na zmienną zależną i przyjąć za prawdziwą hipotezę alternatywną $\mathrm{H}_{3}\left(\chi_{\text {krytyczne }}^{2}\right.$ dla $\alpha=0,01 \mathrm{i} \mathrm{df}=1$ jest równe 6,635, podczas gdy statystyka Walda dla tego predykatora osiagnęła wartość 15,8665$)$. Iloraz szans dla analizowanej zmiennej wynosi 0,1941, więc jest mniejszy od jedności, świadcząc o destymulującym i ujemnym wpływie tego predykatora na ekskluzję finansowa. Wartość tę można zinterpretować następująco: prawdopodobieństwo wykluczenia finansowego osób bezrobotnych spada blisko pięciokrotnie, gdy stopień ich świadomości finansowej wzrasta o jeden poziom. Natomiast przedziały ufności omawianej zmiennej można wyjaśnić w niniejszy sposób: z prawdopodobieństwem 0,99 (99\%) można oczekiwać, że iloraz szans wystapienia wykluczenia finansowego osób bezrobotnych w odniesieniu do świadomości finansowej nie będzie niższy niż 0,0673 i wyższy niż 0,5604 . 
Ostatnia analizowana zmienna niezależna $\mathrm{X}_{4}$ (wykształcenie) jest istotna statystycznie, gdyż p wynosi poniżej 0,01, co pozwala odrzucić $\mathrm{H}_{0}$ o braku wpływu tego predyktora na zmienną zależną i przyjąć za prawdziwą hipotezę alternatywną $\mathrm{H}_{4}\left(\chi_{\text {krytyczne }}^{2}\right.$ dla $\alpha=0,01 \mathrm{i} \mathrm{df}=1$ jest równe 6,635, podczas gdy statystyka Walda w tym przypadku osiągnęła wartość 7,5802). Iloraz szans dla tej zmiennej wynosi 0,2476, czyli jest mniejszy od jedności, dowodzi to destymulującego i ujemnego wpływu tego predykatora na wykluczenie finansowe. Świadczy to o tym, że osoby z wyższym wykształceniem są mniej podatne na ekskluzję finansowa. Dokładnie wartość OR można zinterpretować następująco: prawdopodobieństwo wystapienia wykluczenia finansowego spada blisko czterokrotnie, gdy poziom wykształcenia osoby bezrobotnej wzrasta o jednostkę. Przedział ufności analizowanej zmiennej niezależnej wynosi od 0,0671 do 0,9140.

Po weryfikacji hipotez można przejść do analizy mocy predykcyjnej modelu. Tabela 7. obrazuje zdolności klasyfikacyjne teorii. Celność modelu (ACC) przy punkcie odcięcia 0,5 wynosi $85,6 \%$ i jest wyższa w porównaniu z modelem tylko z wyrazem wolnym, co oznacza, że posiada on wartość dodana. Inne współczynniki, to jest czułość i specyficzność, wynoszą kolejno: $\mathrm{C}=72,7 \%$ i $\mathrm{S}=91,5 \%$.

Tabela klasyfikacyjna

TABELA 7.

\begin{tabular}{|c|c|c|c|c|}
\hline \multicolumn{2}{|c|}{ Klasyfikacja } & \multicolumn{3}{|c|}{ Wartość obserwowana } \\
\hline & & 1 & $\mathbf{0}$ & $\Sigma$ \\
\hline \multirow{3}{*}{$\begin{array}{l}\text { Wartość } \\
\text { przewidywana }\end{array}$} & 1 & 24 & 6 & 30 \\
\hline & 0 & 9 & 65 & 74 \\
\hline & $\Sigma$ & 33 & 71 & 104 \\
\hline
\end{tabular}

Źródło: opracowanie własne z wykorzystaniem Statystycznego Oprogramowania Obliczeniowego PQStat.

Stąd dzięki modelowi sklasyfikowano poprawnie około 86\% klas decyzyjnych, z czego prawidłowo pogrupowanych przypadków pozytywnych jest 73\%, a negatywnych $92 \%$. Widać więc, że o ile teoria potrafi bardzo dobrze prognozować postawy, w odniesieniu do których wykluczenie finansowe nie będzie miało miejsca, to nieco gorzej radzi sobie z predykcją zachowań względem osób, które są podatne na zostanie wykluczonymi z rynku produktów i usług finansowych.

Na podstawie czułości i specyficzności skonstruowano krzywą ROC (rysunek 3.). Pole powierzchni pod krzywą (AUC) wyniosło 0,924 przy p<0,000001, co oznacza, że jest znacznie większe niż 0,5 a tym samym model jest bardzo dobry, ponieważ służy klasyfikacji przypadków znacznie lepiej niż model losowy.

Podsumowujacc, wykluczenie finansowe jest bardziej prawdopodobne u osób bezrobotnych, które maja problemy z zarządzaniem płynnością budżetu gospodarstwa domowego, gdyż cechuje je niska awersja do zadłużania się, są słabo wykształcone, a poziom ich świadomości finansowej jest na niskim poziomie. 


\section{Krzywa ROC}

RYSUNEK 3.

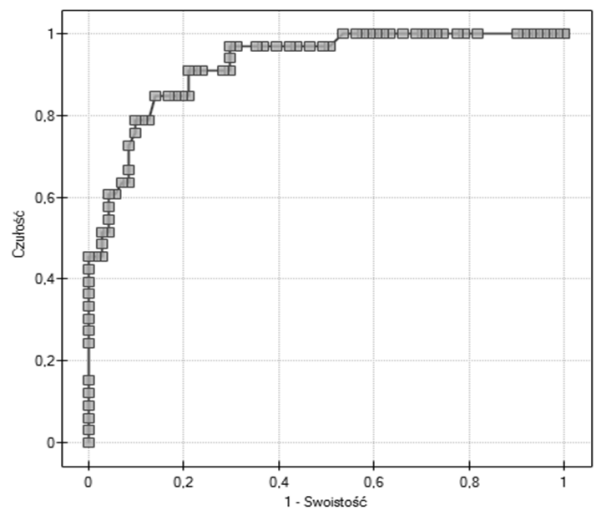

Źródło: opracowanie własne z wykorzystaniem Statystycznego Oprogramowania Obliczeniowego PQStat.

\section{Wybrane sposoby ograniczania wykluczenia finansowego bezrobotnych}

\subsection{Idea odpowiedzialnych finansów}

Istnienie barier, takich jak marginalizacja, oznacza złamanie naczelnej w koncepcji rozwoju zrównoważonego idei sprawiedliwości intrageneracyjnej, a pośrednio także intergeneracyjnej [Rydzewski, 2012, s. 59]. Właściwe rozpoznanie przyczyn wykluczenia finansowego pozwala szukać odpowiednich metod, które mają zapobiegać temu niepożądanemu zjawisku społeczno-ekonomicznemu i je ograniczać. Podejmowane w tym obszarze działania są określane mianem inkluzji finansowej (financial inclusion). Zgodnie z tezami dokumentu Banku Światowego, powinny one wpisywać się w ideę odpowiedzialnych finansów (responsible finance). Nadrzędnym celem tej koncepcji jest: prayyçynianie sie do promowania idei zrónnoważonego rozwoju, stad działania podejmowane w jej ramach powinny stusyć gospodarce, społeczeństwu i środowisku naturalnemu, zarówno w skali poszczególnych państw, jak. i w ujeciu miedsynarodonym (...) a dostep do szerokiej gamy ustug finansonych, w tym dotyczacych oszczedności, ubezpieczenia, keredytu, dostarczanych gospodarstwom domowym i przedsiebiorstwom w sposób odpowiedzialny jest jednym z najważniejszych elementón sk kadonych zrównoważonego w:rostu i ro:swoju [Advancing..., 2011, s. 1]. Zdaniem autorów cytowanego opracowania, odpowiedzialne finanse przejawiają się w skoordynowanych działaniach podejmowanych w systemie finansowym przez publiczne i prywatne podmioty, których celem jest oddziaływanie na instytucje finansowe i ich klientów w taki sposób, aby ostatecznie doprowadzić do stworzenia bardziej inkluzyjnego i sprawiedliwego rynku finansowego.

Przeprowadzone w pierwszej części artykułu badania posłużyły zidentyfikowaniu czynników zwiększających prawdopodobieństwo wykluczenia finansowego wśród osób bezrobotnych. Pozwoliło to w drugiej części opracowania wskazać konkretne kierunki działań inkluzyjnych, z długiej listy proponowanych przez Bank Światowy, realizo- 
wanych w myśl koncepcji odpowiedzialnych finansów. Niska świadomość finansowa, brak umiejętności zarządzania płynnością budżetu gospodarstwa domowego czy duża skłonność do zadłużania się wymagają inicjatyw w następujących obszarach: odpowiedzialny dostawca produktów i usług finansowych, ochrona konsumenta i kształtowanie umiejętności finansowych.

\subsection{Odpowiedzialny dostawca produktów i usług finansowych}

Pierwszym obszarem, na który wskazują eksperci Banku Światowego jest odpowiedzialny dostawca produktów i usług finansowych, taki który przedstawia ofertę produktów „szytych na miarę” potrzeb swoich klientów. Sprzedaje ją rzetelnie, informując o najistotniejszych parametrach, tak aby nabywca mógł podjać właściwa, świadomą decyzję zakupowa.

Z badań przeprowadzonych na potrzeby niniejszego opracowania wynika, że parametrem w znacznym stopniu determinującym wykluczenie finansowe osób bezrobotnych są problemy z zarządzaniem płynnością budżetu gospodarstwa domowego. Oznacza to, że osoby mające często kłopoty finansowe, którym okresowo brakuje środków pieniężnych na bieżące wydatki, są bardziej podatne na wykluczenie finansowe. Takim gospodarstwom domowym jest potrzebny produkt, który pozwoliłby niwelować te chwilowe niedobory. Niestety, instytucje bankowe nie mają w tym zakresie nic do zaoferowania osobom bezrobotnym, które nie posiadaja zdolności kredytowej pozwalającej na to, by otrzymać kartę kredytową czy kredyt w rachunku bieżącym, czyli typowych instrumentów służących zarządzaniu płynnością budżetu gospodarstwa domowego.

Warto sięgnąc do odpowiedzi udzielonych przez ankietowanych na pytanie: „W jakiej sytuacji sięgnąłés/sięgnąbyś po pożyczkę?” Uzyskane wyniki tylko potwierdzają wcześniejsze spostrzeżenia, że bezrobotni potrzebują pieniędzy na krótki okres i w niewielkiej kwocie, głównie po to, by zrównoważyć budżet. Blisko 50\% respondentów wskazało, że wzięłoby pożyczkę, aby sfinansować zakup żywności, odziė̇y, pokryć koszty leczenia, zakupu leków czy opłat stałych (rysunek 4.).

Mikropożyczki internetowe to produkty „,szyte na miarę” potrzeb osób mających przejściowe problemy z równoważeniem dochodów i wydatków budżetu gospodarstwa domowego. Oferuja je niebankowe podmioty pożyczkowe, prowadzące działalność w Internecie. Pierwsze tego rodzaju firmy pojawiły się na polskim rynku kilka lat temu, ale dopiero w latach 2012-2013 wyraźnie zwiększyły sprzedaż swych produktów. NetCredit, Kredito24, Wonga.com, Vivus Finance dynamicznie zdobywają rynek. Ostatni z wymienionych podmiotów w ciągu pierwszego roku od rozpoczęcia działalności, tj. od lipca 2012 roku, obsłużył 300 tys. klientów, udzielając im pożyczek na kwotę 250 mln zł. Przedsiębiorstwa tego typu oferują pożyczki o niskiej wartości z terminem zwrotu do 30 dni. W 2013 roku przeciętna kwota mikropożyczki wynosiła 449 zł w przypadku pierwszej pożyczki zaciaganej przez klienta oraz 745 zł wobec klientów określanych jako „powracający”, którzy zaciagali kolejna pożyczkę w danej firmie po wcześniejszej, pełnej i terminowej spłacie poprzedniej. Mikropożyczki są spłacane jednorazowo lub - na wniosek klienta - przedłużane na następny okres, często ich całkowitym kosztem jest prowizja 
powiększająca kwotę spłacaną na koniec okresu kredytowania. Średnie koszty obsługi długu wynoszą od 19\% do 23\% pożyczonej kwoty [Raport-Mikropożyczki..., 2013, s. 5].

\section{W jakiej sytuacji sięgnął (sięgnąłby) Pan/sięgnęła (sięgnęłaby) Pani po po- życzkę?}

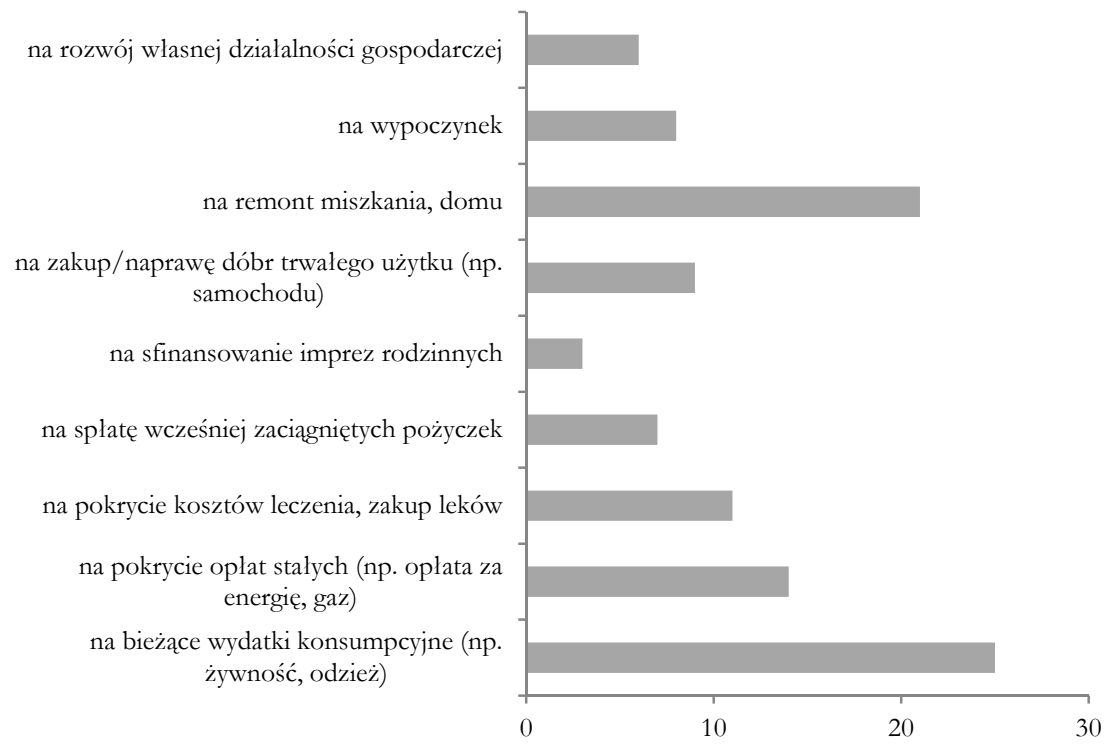

Źródło: opracowanie własne na podstawie wyników przeprowadzonej ankiety.

Ponad 20\% respondentów (rysunek 4.) wskazało na remont mieszkania/domu jako cel zaciagnięcia pożyczki, stąd można powiedzieć, że wydatki miały charakter inwestycyjny, podobnie jak te dotyczące zakupu czy naprawy dóbr trwałego użytku. Banki posiadają w ofertach adekwatne produkty, ale nie dla osób bezrobotnych, więc zainteresowanym pozostaja niebankowe instytucje pożyczkowe. Najwięcej (około 55\%) ankietowanych wybrało Providenta na pożyczkodawcę, dość często wymieniano również Pośrednictwo Finansowe „Kredyty - Chwilówki” Sp. z o.o.

\subsection{Ochrona konsumenta}

Działaniem, które pozwala zapobiegać zjawisku wykluczenia finansowego, jest objęcie szczególną ochrona prawną osób fizycznych, występujących jako konsumenci usług bankowych. W tym obszarze odpowiedzialnych finansów wiodącą rolę odgrywa państwo, z jednej strony jako legislator, a z drugiej jako egzekutor. Przepisy prawa mają chronić interesy słabszego podmiotu występującego na rynku finansowym, a mianowicie każdego konsumenta, w tym bezrobotnego, i jednocześnie budować jego zaufanie do systemu finansowego. $Z$ inicjatywy instytucji rządowych i pozarządowych, po aferze $z$ firmą 
AmberGold, w wyniku której finansowo ucierpiało wielu Polaków, postanowiono bliżej przyjrzeć się działalności parabanków, które to pozyskuja wielu klientów z grona wykluczonych finansowo. W różnych gremiach naukowych, politycznych, biznesowych dyskutowano, czy i jaką rolę powinno odegrać państwo w zakresie regulacji alternatywnego rynku finansowego. Próbowano znaleźć kompromis pomiędzy nadmiernym interwencjonizmem państwowym a samoregulacją sektora shadow banking. Z jednej strony państwo ma chronić interesy słabszych podmiotów, jakimi niewątpliwie są konsumenci, z drugiej strony nie powinno godzić w swobodę działalności gospodarczej.

Uwzględniając fakt, że samoregulacja sektora shadow banking, oparta na idei społecznej odpowiedzialności biznesu (CSR), może okazać się nie dość skuteczna oraz to, że nadmierne zakazy mogą doprowadzić do przejścia firm pożyczkowych do szarej strefy, wprowadzono zmiany do ustawy o nadzorze nad rynkiem finansowym oraz niektórych innych ustaw, które weszły w życie 18 stycznia 2014 roku. Mają one na celu zwiększenie poziomu ochrony uzasadnionych interesów konsumentów dokonujących czynności prawnych z różnymi instytucjami finansowymi, w tym niebankowymi. Nowelizacja wprowadza m.in. zasadę, iż Komisja Nadzoru Finansowego będzie publikować w mediach komunikaty związane z zagrożeniami w zakresie funkcjonowania rynku finansowego, a także obowiązek pożyczkodawców do wyrażania stopy oprocentowania kredytu w stosunku rocznym (więcej patrz: Dz. U. 2013, poz. 1567). Nie znalazły się w niej zapisy dotyczące ograniczania całkowitego kosztu kredytu czy obowiązku zasilania przez kredytodawców kredytów konsumenckich zewnętrznych baz danych, wykorzystywanych do oceny zdolności kredytowej potencjalnych dłużników, o których dyskutowano na etapie rządowego projektu.

W Polsce funkcjonują różne ustawy, które mają chronić interesy konsumentów, w tym również usług bankowych. Wystarczy wymienić: Ustawa o ochronie konkurencï $i$ konsumentów (Dz. U. 2007, Nr 50, poz. 331 z późn. zm.), Ustawa Prawo bankowe (Dz. U. 1997, Nr 140, poz. 939 z późn. zm.), Ustawa o kredycie konsumenckim (Dz. U. 2011, Nr 126, poz. 715 z późn. zm.), tzw. Ustawa antylichwiarska (Ustawa o zmianie ustawy Kodeks cymilny oraz o zmianie niektórych innych ustaw, Dz. U. 2005, Nr 157, poz. 1316), tzw. Ustawa o upadtości konsumenckiej (Ustawa z. 5 grudnia 2008 r. o zmianie ustawy - Prawo upadtościowe $i$ naprawcze oraz. ustawy o kosztach sqdowych w sprawach cywilnych, Dz. U. 2008, Nr 234, poz. 1572 z późn. zm.). Przy czym warto zauważyć, że nawet najlepsze przepisy prawa nie ochronią w należytym stopniu konsumenta, który nie jest ich świadomy. O zapisach art. 54 Ustany o kredycie konsumenckim, który stanowi że konsument ma prawo, bez.podania praycsyny, do odstapienia od umowy o kredyt konsumencki w terminie 14 dni od dnia zawarcia umowy nie wiedziało 49\% ankietowanych. Z kolei, 56,7\% z nich zgodziło się z twierdzeniem: Przepisy prawa w Polsce reguluja maksymalna uysokość oprocentowania pozyczki, zatem catkowity koszt dtugu jest znany. Niezbędna staje się więc akcja edukacyjna, prowadząca do kształtowania zdolności finansowych konsumentów, która stanowi trzeci obszar odpowiedzialnych finansów.

\subsection{Kształtowanie umiejętności finansowych}

Badania przeprowadzone na potrzeby niniejszego opracowania pokazały, że wykluczeniu finansowemu osób bezrobotnych sprzyja niski poziom świadomości finansowej. 
Stąd podejmowane działania inkluzyjne powinny zmierzać do kształtowania zdolności finansowych. Jednym z podmiotów, który ma w tym obszarze dużą rolę do odegrania, jest państwo, rozumiane jako: władze rządowe i samorządowe, banki centralne, instytucje nadzoru czy organizacje zrzeszające konsumentów. Do realizowanych przez nie działań inkluzyjnych, przeciwdziałających wykluczeniu finansowemu, można zaliczyć organizowanie ogólnopolskich kampanii społecznych. Na przykład celem akcji „Zanim podpiszesz" jest zwrócenie uwagi społeczeństwa na ryzyko związane z zawieraniem umów finansowych, w tym przede wszystkim z zaciaganiem wysoko oprocentowanych pożyczek, tzw. „chwilówek”. Współorganizatorami tej inicjatywy sa: Bankowy Fundusz Gwarancyjny, Komisja Nadzoru Finansowego, Ministerstwo Finansów, Ministerstwo Sprawiedliwości, Narodowy Bank Polski, Policja oraz Urząd Ochrony Konkurencji i Konsumentów.

Państwo musi dołożyć wielu starań w zakresie kształtowania zdolności finansowych, ale jego bezwzględna przewaga jest możliwość organizacji kampanii społecznych, które cieszą się dużym zaufaniem, gdyż są obiektywne, nie zawierają elementów skłaniających do zakupu określonych produktów finansowych i docieraja przez mass media do szerokiego grona odbiorców. Mimo to, pojawiają się koszty tego typu działań. Oczywiste jest, że każda inicjatywa musi kosztować i należałoby ją raczej potraktować jako inwestycję w przyszłość. Wzrost świadomości finansowej obywateli w długim okresie może zapobiec np. nadmiernemu zadłużeniu, które spycha ludzi poza główny rynek produktów i usług finansowych stają się oni klientami instytucji pożyczających pieniądze na wysoki procent. Z czasem wpadaja w pętlę zadłużenia, pogłębia się ich ubóstwo, wymagają objęcia ich świadczeniami z opieki społecznej, co, niewątpliwie, obciąża budżet państwa.

Odpowiedzialne finanse, interpretowane z punktu widzenia dostawców produktów i usług finansowych, sprowadzają się do realizacji koncepcji społecznej odpowiedzialności biznesu (CSR). Komisja Europejska w 2001 roku opublikowała Green Paper on CSR, gdzie społeczną odpowiedzialność biznesu zdefiniowano jako koncepcję, według której przedsiębiorstwa dobrowolnie realizują strategie uwzględniające: interesy społeczne, ochronę środowiska, a także relacje z stakeholders [Green Paper..., 2001, s. 6]. Bycie odpowiedzialną instytucją przejawia się zatem nie tylko w spełnianiu wymogów formalnych, wynikających z zasad prawa i ekonomii, ale także w podejmowaniu działań oczekiwanych i pożądanych przez społeczeństwo. Obserwując podmioty funkcjonujące na rynku finansowym, można zauważyć, że coraz więcej z nich uwzględnia w swoich strategiach biznesowych koncepcję CSR. Natomiast wśród podejmowanych przez nie inicjatyw znajdują się również takie, które są ukierunkowane na kształtowanie zdolności finansowych społeczeństwa, a tym samym na walkę z wykluczeniem finansowym. Na przykład Bank BPH zorganizował kampanię „Kobieta w świecie finansów” mająca na celu edukację i wspieranie kobiet w osiaganiu niezależności finansowej czy rozwijaniu przedsiębiorczości. Z kolei, Provident od 2007 roku realizuje program „Akademia Rodzinnych Finansów”, którego celem jest szerzenie wiedzy i rozwijanie umiejętności potrzebnych do efektywnego i odpowiedzialnego zarządzania domowym budżetem. Stowarzyszenie Krzewienia Edukacji Finansowej, dzialające w systemie Spółdzielczych Kas Oszczędnościowo-Kredytowych, uczestniczy w kampanii informacyjnej, skierowanej do osób nadmiernie zadłużonych - zyciewkredycie.pl. 


\section{Podsumowanie}

Konkludując, osoby bezrobotne to podmioty wrażliwe na wykluczenie finansowe. Wykorzystane w niniejszym opracowaniu metody badawcze - model regresji logistycznej i metody opisowe pozwoliły zidentyfikować, jakie czynniki - poza brakiem dochodów, lub niskimi dochodami, sprzyjają wykluczeniu finansowemu tej grupy społecznej. Otóż są to: brak awersji do zadłużania się, niski poziom świadomości finansowej, słabe wykształcenie oraz częste problemy z zarządzaniem płynnością budżetu gospodarstwa domowego. Działania inkluzyjne, które zmierzają do włączenia jak największej liczby osób bezrobotnych do systemu finansowego, a tym samym ograniczenia ważnego problemu społeczno-ekonomicznego, jakim jest wykluczenie finansowe, wpisują się w realizację celów rozwojowych unijnej strategii - „Europa 2020”. Koncentrują się one na następujących obszarach: kształtowanie umiejętności finansowych, ochrona konsumenta czy oferowanie produktów „szytych na miarę” potrzeb osób bezrobotnych.

\section{Literatura}

Advancing Responsible Finance for Greater Development Impact. A Stock-Taking of Strategies and Approaches among Development Agencies and Development Finance Institutions 2011, The German Federal Ministry for Economic Cooperation and Development, The International Finance Corporation and The Consultative Group to Assist the Poor, Berlin, dokument elektroniczny, tryb dostępu: [http://www.ifc.org/wps/ wcm/connect/5886c3804958610ba542b519583b6d16/ResponsibleFinanceRepo rt.pdf?MOD=AJPERES\&CACHEID=5886c3804958610ba542b519583b6d16, data wejścia: 23.12.2013].

Anderloni L. i inni 2008 Financial services provision and prevention of financial exclusion, European Commission, dokument elektroniczny, tryb dostępu: [http://www.esbg.eu/ uploadedFiles/Position_papers/ESBG $\% 20$ Comments $\% 20$ on $\% 20$ Financial $\% 20$ Inclusion.pdf, data wejścia: 15.12.2013].

Chakrabarty K. C. 2006 Financial Inclusion. Concept, Issues and Roadmap, Institute for Development and Research in Banking Technology. Established by Reserve Bank of India, dokument elektroniczny, tryb dostępu: [http://www.idrbt.ac.in, data wejścia: 07.12.2013].

Demirgüç-Kunt A. i inni 2008 Finance for All? Policies and Pitfalls in Expanding Access, The World Bank, Washington.

Europe 2020: a strategy for smart, sustainable and inclusive growth: communication from the Commission 2010, European Commission, dokument elektroniczny, tryb dostępu: [http:/ / ec.europa.eu/europe2020/documents/related-document-type/index_en. htm, data wejścia: 23.12.2013].

Finney D. J. 1971 Probit Analysis, Cambridge University Press, Cambridge.

Green paper - promoting a European Framework for corporate social responsibility 2001, Commission of the European Communities, dokument elektroniczny, tryb dostępu: [http://www.csr-in-commerce.eu/document_library.php/en/717/green-paper-quo 
tpromoting-a-european-framework-for-corporate-social-responsibilityquot-com200 1366-fi, data wejścia: 20.12.2013].

Hosmer D. W., Lemeshow S. 2000 Applied Logistic Regression, John Wiley \& Sons, New York.

Hosmer D., Lemeshow S. 1980 Goodness-of-fit tests for the multiple logistic regression model, „Communications in Statistics - Theory and Methods”, no. 10.

Iwanicz-Drozdowska M. 2011 Edukacja i śniadomość finansowa. Doswiadczenia i perspektywy, Oficyna Wydawnicza SGH w Warszawie, Warszawa.

Kleinbaum D. G., Klein M. 2005 Logistic regression - a self-learning text, New York. Maison D. 2013 Polak w śniecie finansów, Wydawnictwo Naukowe PWN, Warszawa.

McFadden D. 1974 Conditional logit analysis of qualitative choice behavior, [w:] Frontiers in Econometrics, P. Zarembka (red.), New York.

Raport - Mikroposycreki w Polsce 2013, dokument elektroniczny, tryb dostępu: [http://static. squarespace.com/static/51bf101ae4b010d205f86e84/t/5391fdc3e4b0dd94905fec79/ 1402076611218/Mikropo\%C5\%BCyczki\%20w\%20Polsce.pdf, data wejścia: 28.12. 2013].

Rydzewski P. 2012 Marginalizacja spoteczna a rozwój zrównoważony - praylktad bezdomności, „Problemy Ekorozwoju”, nr 1.

Shadow Banking: Strengthening Oversight and Regulation 2011, dokument elektroniczny, tryb dostępu: [http://www.financialstabilityboard.org/publications/r_111027a.pdf, data wejścia 27.12.2013].

World Bank eAtlas of Financial Inclusion 2013, dokument elektroniczny, tryb dostępu: [http://www.app.collinsindicate.com/worldbankatlas-fi/en-us, data wejścia: 28.12. 2013].

\section{Załącznik: Kwestionariusz ankiety}

1. Czy posiada Pan/Pani rachunek oszczędnościowo-rozliczeniowy (konto osobiste) w banku lub SKOK-u ?

\begin{tabular}{|c|c|}
\hline O Tak & $\mathrm{O}$ Nie \\
\hline 1A. W jakiej instytucji ma Pan/Pani konto osobiste? & 1B. Dlaczego nie posiada Pan/Pani konta osobistego? \\
\hline$\square$ PKO BP SA & $\square$ Bank/SKOK odmówił mi zawarcia umowy ra- \\
\hline$\square$ Bank Zachodni WBK SA & chunku \\
\hline$\square$ Pekao SA & $\square$ Nie jestem zainteresowany/a posiadaniem tego \\
\hline$\square \mathrm{SKOK}$ & produktu \\
\hline$\square$ w innej, jakiej?...... & 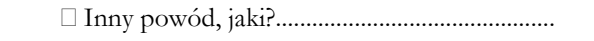 \\
\hline
\end{tabular}

2. Czy posiada Pan/Pani kredyt/pożyczkę w banku lub SKOK-u?

\begin{tabular}{|c|c|}
\hline O Tak & $\mathrm{ONie}$ \\
\hline $\begin{array}{l}\text { 2A. W jakiej instytucji ma Pan/Pani pożyczkę? } \\
\square \text { PKO BP SA }\end{array}$ & $\begin{array}{l}\text { 2B. Czy był Pan/Pani zainteresowany/a wzięciem kredytu } \\
\text { /pożyczki w banku lub SKOK-u? }\end{array}$ \\
\hline$\square$ Bank Zachodni WBK SA & $\square$ Tak, ale bank/SKOK odmówił mi jego udzielenia \\
\hline$\square$ Pekao SA & $\square$ Tak, ale uważam, że w banku nie mam szans na \\
\hline$\square \mathrm{SKOK}$ & kredyt/pożyczkę \\
\hline$\square$ w innej, jakiej?... & $\square \mathrm{Nie}$, nie jestem zainteresowany/a tym produktem \\
\hline
\end{tabular}


3. Czy jest Pan/Pani zadłużony/a w niebankowej instytucji pożyczkowej?

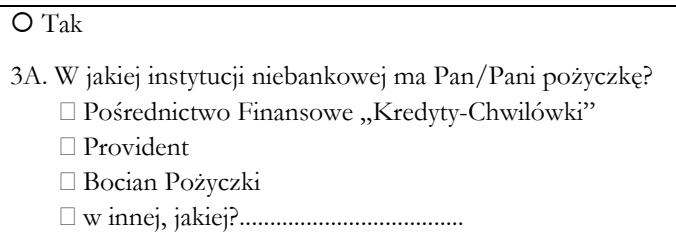

4. Proszę określić swój stosunek do zadłużenia (skłonność do zaciagania pożyczek)

$\square$ Nie mam pożyczek i wcale nie zamierzam zadłużać się

$\square$ Mam pożyczkę, ale planuję jak najszybciej zmniejszyć zadłużenie

$\square$ Nie mam pożyczek, ale planuję zadłużyć się

$\square$ Mam pożyczkę i planuję utrzymać poziom zadłużenia na dotychczasowym poziomie

$\square$ Mam pożyczkę i nadal planuję zwiększać zadłużenie

5. W jakiej sytuacji sięgnął (sięgnąłby) Pan/ sięgnęła (sięgnęłaby) Pani po pożyczkę?

$\square$ Na bieżące wydatki konsumpcyjne (np. żywność, odzież)

$\square$ Na pokrycie opłat stałych (np. opłata za energię, gaz)

$\square$ Na pokrycie kosztów leczenia, zakup leków

$\square$ Na spłatę wcześniej zaciagniętych pożyczek

$\square \mathrm{Na}$ sfinansowanie imprez rodzinnych

$\square \mathrm{Na}$ zakup/naprawę dóbr trwałego użytku (np.. samochodu)

$\square \mathrm{Na}$ remont mieszkania, domu

$\square$ Na wypoczynek

$\square$ Na rozwój własnej działalności gospodarczej

$\square \mathrm{Na}$ inny cel, jaki?

6. Czy ma Pan/Pani problemy z bieżącym regulowaniem swoich zobowiązań?

$\square$ Tak, często

$\square$ Zdarzają się raz, dwa razy do roku

$\square$ Wcale nie mam problemów

7. Czy zgadza się Pan/Pani ze stwierdzeniem?

\begin{tabular}{|c|c|c|c|c|}
\hline Treść & Tak & $\begin{array}{l}\text { Raczej } \\
\text { tak }\end{array}$ & $\begin{array}{l}\text { Raczej } \\
\text { nie }\end{array}$ & $\mathrm{Nie}$ \\
\hline $\begin{array}{l}\text { Przepisy prawa regulują w Polsce maksymalną wysokość odsetek, zatem cał- } \\
\text { kowity koszt pożyczki jest znany }\end{array}$ & & & & \\
\hline $\begin{array}{l}\text { Od momentu podpisania umowy o kredyt konsumencki nie można się z niej } \\
\text { już wycofać }\end{array}$ & & & & \\
\hline $\begin{array}{l}\text { Atrakcyjnym dla klienta rozwiązaniem są kredyty } 0 \% \text { oferowane w sklepach, } \\
\text { nic nie kosztują }\end{array}$ & & & & \\
\hline $\begin{array}{l}\text { Osoba która miała w przeszłości problemy ze spłata kredytu i jest uwidocz- } \\
\text { niona w bazie BIK nie ma już szansy na kredyt w banku }\end{array}$ & & & & \\
\hline $\begin{array}{l}\text { Oprocentowanie pożyczki udzielonej przez instytucję niebankową może wy- } \\
\text { nieść } 500 \% \text { p.a. }\end{array}$ & & & & \\
\hline
\end{tabular}

\section{METRYCZKA:}

\begin{tabular}{|l|l|l|l|l|l|l|}
\hline Płeć & $\square$ kobieta & \multicolumn{4}{|l|}{ mężczyzna } \\
\hline Wiek & $\square$ poniżej 25 lat & $\square$ 25-35 lat & $\square$ 35-44 lat & $\square$ 45-54 lat & $\square$ powyżej 55 lat \\
\hline Wykształcenie & $\square$ podstawowe & $\square$ zasadnicze zawodowe & $\square$ średnie & $\square$ policealne i wyższe \\
\hline
\end{tabular}

